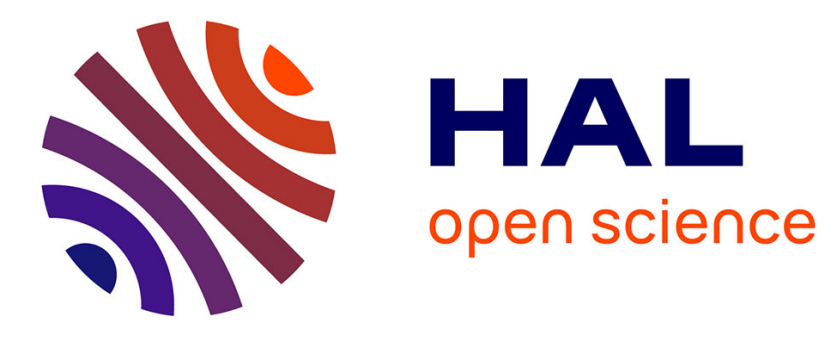

\title{
Embryonic stem cell markers expression in cancers.
} Matthieu Schoenhals, Alboukadel Kassambara, John De Vos, Dirk Hose, Jérôme Moreaux, Bernard Klein

\section{To cite this version:}

Matthieu Schoenhals, Alboukadel Kassambara, John De Vos, Dirk Hose, Jérôme Moreaux, et al.. Embryonic stem cell markers expression in cancers.. Biochemical and Biophysical Research Communications, 2009, 383, pp.157-162. 10.1016/j.bbrc.2009.02.156 . inserm-00367054

\section{HAL Id: inserm-00367054 https://www.hal.inserm.fr/inserm-00367054}

Submitted on 10 Mar 2009

HAL is a multi-disciplinary open access archive for the deposit and dissemination of scientific research documents, whether they are published or not. The documents may come from teaching and research institutions in France or abroad, or from public or private research centers.
L'archive ouverte pluridisciplinaire $\mathbf{H A L}$, est destinée au dépôt et à la diffusion de documents scientifiques de niveau recherche, publiés ou non, émanant des établissements d'enseignement et de recherche français ou étrangers, des laboratoires publics ou privés. 


\section{Embryonic stem cell markers expression in cancers}

Matthieu Schoenhals ${ }^{\ddagger}$, Alboukadel Kassambara ${ }^{\ddagger}$, John De Vos ${ }^{\star \ddagger \dagger}$, Dirk Hose ${ }^{\circ}$, Jérôme Moreaux $^{\star \ddagger}$, Bernard Klein* ${ }^{\star \ddagger}$

* CHU Montpellier, Institute of Research in Biotherapy, Montpellier, FRANCE;

‡ INSERM, U847, Montpellier, F-34197 France;

† Université MONTPELLIER1, UFR Médecine, Montpellier, France;

'Medizinische Klinik und Poliklinik V, Universitätsklinikum Heidelberg, Heidelberg, Germany

Corresponding author: Pr. Bernard KLEIN INSERM U847, Institute of Research in Biotherapy, CHU Montpellier, Av Augustin Fliche 34285 Montpellier cedex, FRANCE Tel 33-(0)467337888 Fax 33-(0)467337905

Mail: bernard.klein@montp.inserm.fr http://irb.chu-montpellier.fr/index.htm 


\begin{abstract}
:
The transcription factors Oct4 and Sox2 are highly expressed in embryonic stem (ES) cells. In conjunction with KIf4 and c-Myc, their over-expression can induce pluripotency in both mouse and human somatic cells, indicating that these factors are key regulators of the signaling network necessary for ES cell pluripotency. Self-renewal is a hallmark of stem cells and cancer and stemness program could play an important role in cancer.

Therefore we compared the expression of Oct4, Sox2, Klf4 and c-Myc in 40 human tumor types to that of their normal tissue counterparts using publicly available gene expression data, including the Oncomine Cancer Microarray database.

We found significant overexpression of at least $1 / 4$ pluripotency factors Oct4, Sox2, KIf4 or c-Myc in 18 out of the 40 cancer types investigated. Furthermore, within a given tumor category these genes are associated with tumor progression or bad prognosis. A key goal in cancer research is to identify the mechanism by which cancer stem cells arise and self-renew. The overexpression of Oct3/4, Sox2, KIf4 and/or c-Myc could contribute to the pathologic self-renewal characteristics of cancer stem cells.
\end{abstract}




\section{Introduction}

Oct3/4, Sox2, Klf4, c-Myc are expressed in embryonic stem (ES) cells, and their over-expression can induce pluripotency in both mouse and human somatic cells, indicating that these factors regulate the developmental signaling network necessary for ES cell pluripotency[1;2].

Cancer stem cells refer to a subset of tumor cells that has the ability to self-renew and generate tumor heterogeneity $[3 ; 4 ; 5]$.

Oct4 is a major transcription factor that is mandatory for the self-renewal and pluripotency characteristics of ES cells and germ cells. Rare cells that express Oct4 were identified in several somatic cancers[6]. Oct4A expressing cells are present in human benign and malignant prostate glands and the frequency of Oct4A expressing cells increases in prostate cancers[6]. A subpopulation of the Oct4A expressing cells coexpressed Sox2, an ES cell marker[6]. In the intestine, Oct4 expression causes dysplasia by inhibiting cellular differentiation in a manner similar to that in the ES cells[7].

In the mouse nervous system, Sox2 is expressed in neural stem cells, in early precursors and in few mature neurons, and is essential to maintain the cell proliferative potential[8; 9]. Sox2 is also expressed in several malignant tissues[10; 11; 12; 13]. These data and the known role of Sox2 in development and cell differentiation suggest that this transcription factor may be relevant to the aberrant growth of tumor cells.

Myc has a gene activation function, a finding consistent with Myc ability to recruit multiple coactivator complexes[14; 15]. The ability of Myc to bind to a staggeringly large number of genomic loci has also been demonstrated in ES cells[16] and is likely to 
underlie its activity as part of the "magic quartet" of transcription factors that can reprogram somatic cells to pluripotency $[1 ; 17 ; 18 ; 19]$. High levels of Myc may block cell differentiation and enhance self-renewal of committed and differentiated cells[20]. During tumor progression, Myc would promote the formation of cancer-initiating cells that retain developmental plasticity. Expression of Myc in hematopoietic stem cells leads to the rapid formation of pre B-cell lymphomas if apoptosis is blocked by coexpression of $\mathrm{Bcl}-2$. Cells derived from these lymphomas can be differentiated into either B-lymphocytes or macrophages in vitro[21]. Similarly, cells derived from liver tumors generated using an inducible Myc transgene differentiate into hepatocytes and biliary cells that go on to form bile ducts when the transgene is turned off [22]. A key function of Myc during normal development is to drive expansion of transit amplifying cells. Due to this unique combination of properties, oncogenic deregulation of Myc expression generates cells possessing a tumor phenotype that has no counterpart during normal development[20]. Kruppel-like factor 4 (KIf4) is a transcription factor expressed in a wide variety of tissues in humans and is important for many different physiological processes, including development, differentiation, and maintenance of normal tissue homeostasis[23]. KIf4 is a transcription factor that can either activate or repress transcription, depending on the target gene. Klf4 can function as an oncogene or a tumor suppressor depending on the type of cancer involved[23]. Klf4 is an anti-proliferative factor in differentiated epithelia, and acts as a tumor suppressor in gastrointestinal cancers[24; 25]. However, Klf4 might also act as an oncogene [26]. It is overexpressed in laryngeal squamous cell carcinoma as an early event in its progression[27]. KIf4 expression is increased in ductal carcinoma of the breast[28] and is associated with an aggressive phenotype and poorer prognosis[29]. In the skin, overexpression of Klf4 results in hyperplasia and dysplasia, 
eventually leading to squamous cell carcinoma[30; 31].

Recently, Ben-Porath et al. identified a subset of ES-cell associated transcription regulators that are highly expressed in poorly differentiated tumors revealing a link between genes associated with ES cell identity and the histopatology of tumors[32].

Cancers arise from a cancer stem cell, able of self-renewal and forming tumor hereterogeneity. The frequency of cancer stem cells is a matter of debate, depending of the technique used to detect it and the cancer type[5;33]. Given the critical role of Oct3/4, Sox2, KIf4 and c-Myc to confer on adult cells self-renewal and pluripotency and their role in cancer, we have reviewed here the expression of Oct3/4, Sox2, KIf4 and cMyc in various cancers, in comparison with their normal counterparts and in association with cancer staging.

\section{Methods}

\section{Databases}

We used Oncomine cancer microarray database (http://www.oncomine.org)[34], Amazonia database (http://amazonia.montp.inserm.fr/)[35] and RAGE database (http://rage.montp.inserm.fr.gate2.inist.fr)[36] to study gene expression of Oct3/4, Sox2, Klf4 and c-Myc in 40 human tumor types and their normal tissue counterparts as indicated in Table 1. In order to compare the gene expression in a tumor type to its normal counterpart, gene expression data from a same study, performed with the same methodology, were used. The gene expression data were log transformed, median centered per array, and the standard deviation was normalized to one per array[34]. A gene was considered as overexpressed when its mean value in tumor samples was 
significantly higher to its mean value in the normal tissue counterpart using a t test $(P \leq$ $.05)$.

\section{Statistical analysis}

Statistical comparisons were done with Mann Whitney or student t-test.

\section{Results and discussion}

We investigated the expression of Oct3/4, Sox2, KIf4 and c-Myc in cancer using publicly available gene expression data. The 40 tumor types investigated corresponded to 4 hematological malignancies and 36 solid tumors (Table 1 ).

\section{Oct4 is overexpressed in solid and hematological malignancies}

We found Oct4 overexpression in 1/4 hematological cancers and 10/36 solid tumors (Table 1). Overexpression of Oct4 was found in in CLL; oligodendroglioma, glioblastoma multiforme and astrocytoma; in bladder carcinoma; in primary colon cancer; in lung adenocarcinoma; in prostate cancer; in testis tumor; in ovarian carcinoma; in pancreatic cancer and in clear cell carcinoma compared to their normal counterpart tissues (Supplementary Figure S1).

\section{Sox2 is overexpressed in solid tumors}

Sox 2 was significantly overexpressed in $7 / 36$ solid tumors (Table 1). Overexpression of Sox2 was found in brain cancers; in hepatocellular carcinoma; in bladder carcinoma; in primary colon cancer; in lung adenocarcinoma; in prostate cancer and in seminoma compared to their normal counterpart tissues (Supplementary Figure S2). 
KLF4 is overexpressed in all hematological malignancies and in some solid tumors

KIf4 was significantly overexpressed in in 1/4 hematological cancers and $7 / 36$ solid tumors (Table 1): in acute lymphoblastic leukemia; in hairy cell leukemia; in multiple myeloma; in brain tumors; in prostate cancer; in yolk sac tumor compared to their normal counterpart tissues (Supplementary Figure S3).

C-Myc is overexpressed in solid and hematological malignancies

We found $c-M y c$ overexpression in all hematological cancers and in 10/36 solid tumors (Table 1). Overexpression of $c-M y c$ was found in leukemia; in lymphoma; in smoldering myeloma and in multiple myeloma; in brain tumors; in head and neck cancer; in primary colon cancer compared to normal adjacent mucosa; in breast carcinoma compared to normal breast; in lung adenocarcinoma; in tongue squamous cell carcinoma; in pancreatic cancer; in prostate cancer; in seminoma; in clear cell carcinoma and in salivary-gland tumors compared to their normal counterpart tissues (Supplementary Figure S4).

Correlations between Oct4, Sox2, KIf4 and c-Myc expression in tumor cells Oct4, Sox2, KIf4 and Myc are all co-overexpressed in 2/40 tumors: i.e. in prostate and brain cancers compared to normal counterparts (Table 1). 3 of these 4 factors were cooverexpressed in leukemia, lung tumors and testis cancer compared to their normal conterparts (Table 1). 2 factors were co-overexpressed in 5/40 tumor types: i.e. multiple myeloma, colon, bladder, pancreas and kidney. At least 1 out of the 4 pluripotency factors were overexpressed in 3/4 hematological cancers and in 15/40 solid tumors.

Link between Oct4, Sox2, KIf4 and c-Myc expression and tumor grade 
Thus, we sought to find out whether Oct4, Sox2, Klf4 and Myc expression could be associated with tumor progression and prognosis.

Oct4 was significantly overexpressed in glioma grade IV compared to grade II and III; in poorly differentiated breast carcinoma compared to well differentiated tumors from patients; in head and neck cancers grade IV compared to grade I and in metastatic sarcoma compared to non metatstatic sacrcoma (Table 2 and Supplementary Figure S5).

Sox2 is overexpressed in bladder carcinoma grade III compare to grade I; in glioma grade IV compared to grade II and III; in head and neck cancers grade III and IV compared to grade I and II; in breast tumors grade III compared to grade I in 8 independent studies; in colorectal carcinoma T stage 4 compared to $\mathrm{T}$ stages Tis and $\mathrm{T} 1$; in cervical carcinoma stage IV compared to stage I; in endometrial carcinoma stage IV compared to stage I and $\mathrm{T}$ stage 4 compared to $\mathrm{T}$ stage 1 ; in metastatic sarcoma compared to non metastatic sarcoma; in metastatic papillary renal cell carcinoma compared to non metastatic papillary renal cell carcinoma and in thyroid gland carcinoma stage IV compared to stage I (Table 2 and Supplementary Figure S6).

KIf4 is overexpressed in metastatic ovarian carcinoma compared to non metastatic ovarian carcinoma; in prostate carcinoma stage III compared to stage II and in primary melanoma tumors $\mathrm{N}$ stage 1 compared to $\mathrm{N}$ stage 0 (Table 2 and Supplementary Figure S7).

C-Myc is overexpressed in poorly differentiated lung adenocarcinoma compared to well differentiated lung carcinoma; in ovarian carcinoma grade IV compared to grade I; in poorly differentiated pancreatic ductal adenocarcinoma compared to well differentiated pancreatic ductal adenocarcinoma; in breast carcinoma grade III compared to grade I; in 
breast ductal carcinoma stage N1 compared to stage N0; in mantle cell lymphoma grade IV compared to grade I; in metatstatic sarcoma compared to primary sarcoma and in melanoma stage N1 compared to stage N0 (Table 2 and Supplementary Figure S8).

Sox2 has been found expressed in a variable percentage of cells in several malignant tissues $[10 ; 11 ; 12 ; 13]$ and is essential to maintain the cell proliferative potential of neural stem cells[8; 9]. Furthermore Sox2 is overexpressed in patients with ovarian carcinoma dead at 5 years compared to patients alive at 5 years $(P=.001)[37]$ and in patients with melanoma metastasis tumor dead at 3 years compared to patients alive at 3 years $(P=.007)[38]$ (Table 3 and Figure 1).

C-Myc is overexpressed in patients with non-small cell lung cancer dead at 5 years compared to patients alive at 5 years $(P=.007)[39]$; in patients with glioma dead at 3 years compared to patients alive at 3 years $(P=.008)[40]$; in patients with breast carcinoma dead at 5 years compared to patients alive at 5 years $(P=.007)[41]$; in patients with diffuse large B-cell lymphoma dead at 5 years compared to patients alive at 5 years $(P=.006$ and $P=.007)[42 ; 43]$; in patients with Burkitt's lymphoma dead at 5 years compared to patients alive at 5 years $(P=.006)[44]$ and in 1 year relapsing multiple myeloma patients compared to patients with no relapse at 1 year $(P=.001)[45]$ (Table 3 and Figure 1). Oct4 and Klf4 expressions were not associated with prognostic in the 40 tumor types investigated (Table 3).

\section{Conclusions:}

A key goal in cancer research is to identify the mechanism by which cancer stem cells arise and self-renew. We have shown here that at least one gene coding for $1 / 4$ pluripotency factors - Oct4, Sox2, Klf4, and c-Myc - is overexpressed in 18/40 cancer types investigated. In addition, for a given tumour, the expression of these genes is 
associated with tumor progression or bad prognosis. The activation of an ES cell-like transcriptional program in differentiated adult cells may induce pathologic self-renewal characteristics of cancer stem cells. In particular, it was recently demonstrated that cMyc activates an embryonic stem cell like program in epithelial cells leading to epithelial tumor initiating cells[46]. Cancer stem cells are so named because they possess qualities reminiscent of normal tissue stem cells including self-renewal, prolonged survival, and the ability to give rise to cells with more differentiated characteristics. Effort is now focused on identifying cancer stem cells in various malignancies, and defining the cells of origin. This review of publicly available data emphasizes the cancer types associated with Oct3/4, Sox2, KIf4 and/or c-Myc overexpression and may encourage further studies to address the role of these pluripotent transcription factors in these cancers. 


\section{Acknowledgements}

This work was supported by grants from the Ligue Nationale Contre le Cancer (équipe labellisée), Paris, France, from INCA ( ${ }^{\circ}$ R07001FN) and from MSCNET European strep ( $\left.\mathrm{N}^{\circ} \mathrm{E} 06005 \mathrm{FF}\right)$. 


\section{Figure legends}

Figure 1: Association of Sox2 and c-Myc expression with prognosis

A. c-Myc expression in multiple myeloma relapsing patients and patients with no relapse[45], in alive patients with and dead patients with breast carcinoma,[41] , in MM patients with no relapse, in MM patients with relapse[45], in alive and dead patients with diffuse large B cell lymphoma[42; 43], in alive and dead patients with Burkitt's lymphoma[44], in alive and dead patients with lung cancer[39], in alive and dead patients with brain cancer[40].

B. Sox2 expression in alive and dead patients with ovarian carcinoma [37] and in alive and dead patients with melanoma metastasis tumor[38]. Patients with mutliple myeloma without Sox2 expression (Affymetrix call) have a better event free survival (EFS) and overall survival (OAS) than patients expressing Sox2. 


\section{References}

[1] K. Takahashi, K. Tanabe, M. Ohnuki, M. Narita, T. Ichisaka, K. Tomoda, and S. Yamanaka, Induction of pluripotent stem cells from adult human fibroblasts by defined factors. Cell 131 (2007) 861-72.

[2] K. Takahashi, and S. Yamanaka, Induction of pluripotent stem cells from mouse embryonic and adult fibroblast cultures by defined factors. Cell 126 (2006) 66376.

[3] M.F. Clarke, J.E. Dick, P.B. Dirks, C.J. Eaves, C.H. Jamieson, D.L. Jones, J. Visvader, I.L. Weissman, and G.M. Wahl, Cancer stem cells--perspectives on current status and future directions: AACR Workshop on cancer stem cells. Cancer Res 66 (2006) 9339-44.

[4] T. Reya, S.J. Morrison, M.F. Clarke, and I.L. Weissman, Stem cells, cancer, and cancer stem cells. Nature 414 (2001) 105-11.

[5] J.E. Visvader, and G.J. Lindeman, Cancer stem cells in solid tumours: accumulating evidence and unresolved questions. Nat Rev Cancer 8 (2008) 755-68.

[6] P. Sotomayor, A. Godoy, G.J. Smith, and W.J. Huss, Oct4A is expressed by a subpopulation of prostate neuroendocrine cells. Prostate (2008).

[7] K. Hochedlinger, Y. Yamada, C. Beard, and R. Jaenisch, Ectopic expression of Oct-4 blocks progenitor-cell differentiation and causes dysplasia in epithelial tissues. Cell 121 (2005) 465-77.

[8] M. Bani-Yaghoub, R.G. Tremblay, J.X. Lei, D. Zhang, B. Zurakowski, J.K. Sandhu, B. Smith, M. Ribecco-Lutkiewicz, J. Kennedy, P.R. Walker, and M. Sikorska, Role of Sox2 in the development of the mouse neocortex. Dev Biol 295 (2006) 52-66.

[9] M. Cavallaro, J. Mariani, C. Lancini, E. Latorre, R. Caccia, F. Gullo, M. Valotta, S. DeBiasi, L. Spinardi, A. Ronchi, E. Wanke, S. Brunelli, R. Favaro, S. Ottolenghi, and S.K. Nicolis, Impaired generation of mature neurons by neural stem cells from hypomorphic Sox2 mutants. Development 135 (2008) 541-57.

[10] R.M. Gangemi, F. Griffero, D. Marubbi, M. Perera, M.C. Capra, P. Malatesta, G.L. Ravetti, G.L. Zona, A. Daga, and G. Corte, SOX2 Silencing in Glioblastoma Tumor Initiating Cells Causes Stop of Proliferation and Loss of Tumorigenicity. Stem Cells (2008).

[11] G. Gu, J. Yuan, M. Wills, and S. Kasper, Prostate cancer cells with stem cell characteristics reconstitute the original human tumor in vivo. Cancer Res 67 (2007) 4807-15.

[12] S.M. Rodriguez-Pinilla, D. Sarrio, G. Moreno-Bueno, Y. Rodriguez-Gil, M.A. Martinez, L. Hernandez, D. Hardisson, J.S. Reis-Filho, and J. Palacios, Sox2: a possible driver of the basal-like phenotype in sporadic breast cancer. Mod Pathol 20 (2007) 474-81.

[13] R. Spisek, A. Kukreja, L.C. Chen, P. Matthews, A. Mazumder, D. Vesole, S. Jagannath, H.A. Zebroski, A.J. Simpson, G. Ritter, B. Durie, J. Crowley, J.D. Shaughnessy, Jr., M.J. Scanlan, A.O. Gure, B. Barlogie, and M.V. Dhodapkar, 
Frequent and specific immunity to the embryonal stem cell-associated antigen SOX2 in patients with monoclonal gammopathy. J Exp Med 204 (2007) 831-40.

[14] S. Adhikary, and M. Eilers, Transcriptional regulation and transformation by Myc proteins. Nat Rev Mol Cell Biol 6 (2005) 635-45.

[15] M.D. Cole, and M.A. Nikiforov, Transcriptional activation by the Myc oncoprotein. Curr Top Microbiol Immunol 302 (2006) 33-50.

[16] J.B. Kim, H. Zaehres, G. Wu, L. Gentile, K. Ko, V. Sebastiano, M.J. Arauzo-Bravo, D. Ruau, D.W. Han, M. Zenke, and H.R. Scholer, Pluripotent stem cells induced from adult neural stem cells by reprogramming with two factors. Nature 454 (2008) 646-50.

[17] J. Hanna, S. Markoulaki, P. Schorderet, B.W. Carey, C. Beard, M. Wernig, M.P. Creyghton, E.J. Steine, J.P. Cassady, R. Foreman, C.J. Lengner, J.A. Dausman, and $\mathrm{R}$. Jaenisch, Direct reprogramming of terminally differentiated mature $B$ lymphocytes to pluripotency. Cell 133 (2008) 250-64.

[18] K. Okita, T. Ichisaka, and S. Yamanaka, Generation of germline-competent induced pluripotent stem cells. Nature 448 (2007) 313-7.

[19] M. Wernig, A. Meissner, R. Foreman, T. Brambrink, M. Ku, K. Hochedlinger, B.E. Bernstein, and $\mathrm{R}$. Jaenisch, In vitro reprogramming of fibroblasts into a pluripotent ES-cell-like state. Nature 448 (2007) 318-24.

[20] M. Eilers, and R.N. Eisenman, Myc's broad reach. Genes Dev 22 (2008) 2755-66.

[21] A. Strasser, A.G. Elefanty, A.W. Harris, and S. Cory, Progenitor tumours from Emubcl-2-myc transgenic mice have lymphomyeloid differentiation potential and reveal developmental differences in cell survival. EMBO J 15 (1996) 3823-34.

[22] C.M. Shachaf, A.M. Kopelman, C. Arvanitis, A. Karlsson, S. Beer, S. Mandl, M.H. Bachmann, A.D. Borowsky, B. Ruebner, R.D. Cardiff, Q. Yang, J.M. Bishop, C.H. Contag, and D.W. Felsher, MYC inactivation uncovers pluripotent differentiation and tumour dormancy in hepatocellular cancer. Nature 431 (2004) 1112-7.

[23] P.M. Evans, and C. Liu, Roles of Krupel-like factor 4 in normal homeostasis, cancer and stem cells. Acta Biochim Biophys Sin (Shanghai) 40 (2008) 554-64.

[24] B.B. McConnell, A.M. Ghaleb, M.O. Nandan, and V.W. Yang, The diverse functions of Kruppel-like factors 4 and 5 in epithelial biology and pathobiology. Bioessays 29 (2007) 549-57.

[25] D. Wei, M. Kanai, S. Huang, and K. Xie, Emerging role of KLF4 in human gastrointestinal cancer. Carcinogenesis 27 (2006) 23-31.

[26] B.D. Rowland, and D.S. Peeper, KLF4, p21 and context-dependent opposing forces in cancer. Nat Rev Cancer 6 (2006) 11-23.

[27] K.W. Foster, S. Ren, I.D. Louro, S.M. Lobo-Ruppert, P. McKie-Bell, W. Grizzle, M.R. Hayes, T.R. Broker, L.T. Chow, and J.M. Ruppert, Oncogene expression cloning by retroviral transduction of adenovirus E1A-immortalized rat kidney RK3E cells: transformation of a host with epithelial features by c-MYC and the zinc finger protein GKLF. Cell Growth Differ 10 (1999) 423-34.

[28] K.W. Foster, A.R. Frost, P. McKie-Bell, C.Y. Lin, J.A. Engler, W.E. Grizzle, and J.M. Ruppert, Increase of GKLF messenger RNA and protein expression during progression of breast cancer. Cancer Res 60 (2000) 6488-95.

[29] A.Y. Pandya, L.I. Talley, A.R. Frost, T.J. Fitzgerald, V. Trivedi, M. Chakravarthy, D.C. Chhieng, W.E. Grizzle, J.A. Engler, H. Krontiras, K.I. Bland, A.F. LoBuglio, S.M. Lobo-Ruppert, and J.M. Ruppert, Nuclear localization of KLF4 is associated 
with an aggressive phenotype in early-stage breast cancer. Clin Cancer Res 10 (2004) 2709-19.

[30] K.W. Foster, Z. Liu, C.D. Nail, X. Li, T.J. Fitzgerald, S.K. Bailey, A.R. Frost, I.D. Louro, T.M. Townes, A.J. Paterson, J.E. Kudlow, S.M. Lobo-Ruppert, and J.M. Ruppert, Induction of KLF4 in basal keratinocytes blocks the proliferationdifferentiation switch and initiates squamous epithelial dysplasia. Oncogene 24 (2005) 1491-500.

[31] C.C. Huang, Z. Liu, X. Li, S.K. Bailey, C.D. Nail, K.W. Foster, A.R. Frost, J.M. Ruppert, and S.M. Lobo-Ruppert, KLF4 and PCNA identify stages of tumor initiation in a conditional model of cutaneous squamous epithelial neoplasia. Cancer Biol Ther 4 (2005) 1401-8.

[32] I. Ben-Porath, M.W. Thomson, V.J. Carey, R. Ge, G.W. Bell, A. Regev, and R.A. Weinberg, An embryonic stem cell-like gene expression signature in poorly differentiated aggressive human tumors. Nat Genet 40 (2008) 499-507.

[33] E. Quintana, M. Shackleton, M.S. Sabel, D.R. Fullen, T.M. Johnson, and S.J. Morrison, Efficient tumour formation by single human melanoma cells. Nature 456 (2008) 593-8.

[34] D.R. Rhodes, J. Yu, K. Shanker, N. Deshpande, R. Varambally, D. Ghosh, T. Barrette, A. Pandey, and A.M. Chinnaiyan, ONCOMINE: a cancer microarray database and integrated data-mining platform. Neoplasia 6 (2004) 1-6.

[35] S. Assou, T. Le Carrour, S. Tondeur, S. Strom, A. Gabelle, S. Marty, L. Nadal, V. Pantesco, T. Reme, J.P. Hugnot, S. Gasca, O. Hovatta, S. Hamamah, B. Klein, and J. De Vos, A meta-analysis of human embryonic stem cells transcriptome integrated into a web-based expression atlas. Stem Cells 25 (2007) 961-73.

[36] T. Reme, D. Hose, J. De Vos, A. Vassal, P.O. Poulain, V. Pantesco, H. Goldschmidt, and B. Klein, A new method for class prediction based on signedrank algorithms applied to Affymetrix microarray experiments. BMC Bioinformatics 9 (2008) 16.

[37] A.H. Bild, G. Yao, J.T. Chang, Q. Wang, A. Potti, D. Chasse, M.B. Joshi, D. Harpole, J.M. Lancaster, A. Berchuck, J.A. Olson, Jr., J.R. Marks, H.K. Dressman, M. West, and J.R. Nevins, Oncogenic pathway signatures in human cancers as a guide to targeted therapies. Nature 439 (2006) 353-7.

[38] L. Xu, S.S. Shen, Y. Hoshida, A. Subramanian, K. Ross, J.P. Brunet, S.N. Wagner, S. Ramaswamy, J.P. Mesirov, and R.O. Hynes, Gene expression changes in an animal melanoma model correlate with aggressiveness of human melanoma metastases. Mol Cancer Res 6 (2008) 760-9.

[39] S. Tomida, K. Koshikawa, Y. Yatabe, T. Harano, N. Ogura, T. Mitsudomi, M. Some, K. Yanagisawa, T. Takahashi, and H. Osada, Gene expression-based, individualized outcome prediction for surgically treated lung cancer patients. Oncogene 23 (2004) 5360-70.

[40] R. Shai, T. Shi, T.J. Kremen, S. Horvath, L.M. Liau, T.F. Cloughesy, P.S. Mischel, and S.F. Nelson, Gene expression profiling identifies molecular subtypes of gliomas. Oncogene 22 (2003) 4918-23.

[41] C. Desmedt, F. Piette, S. Loi, Y. Wang, F. Lallemand, B. Haibe-Kains, G. Viale, M. Delorenzi, Y. Zhang, M.S. d'Assignies, J. Bergh, R. Lidereau, P. Ellis, A.L. Harris, J.G. Klijn, J.A. Foekens, F. Cardoso, M.J. Piccart, M. Buyse, and C. Sotiriou, Strong time dependence of the 76-gene prognostic signature for node-negative 
breast cancer patients in the TRANSBIG multicenter independent validation series. Clin Cancer Res 13 (2007) 3207-14.

[42] A.A. Alizadeh, M.B. Eisen, R.E. Davis, C. Ma, I.S. Lossos, A. Rosenwald, J.C. Boldrick, H. Sabet, T. Tran, X. Yu, J.I. Powell, L. Yang, G.E. Marti, T. Moore, J. Hudson, Jr., L. Lu, D.B. Lewis, R. Tibshirani, G. Sherlock, W.C. Chan, T.C. Greiner, D.D. Weisenburger, J.O. Armitage, R. Warnke, R. Levy, W. Wilson, M.R. Grever, J.C. Byrd, D. Botstein, P.O. Brown, and L.M. Staudt, Distinct types of diffuse large B-cell lymphoma identified by gene expression profiling. Nature 403 (2000) 503-11.

[43] M.A. Shipp, K.N. Ross, P. Tamayo, A.P. Weng, J.L. Kutok, R.C. Aguiar, M. Gaasenbeek, M. Angelo, M. Reich, G.S. Pinkus, T.S. Ray, M.A. Koval, K.W. Last, A. Norton, T.A. Lister, J. Mesirov, D.S. Neuberg, E.S. Lander, J.C. Aster, and T.R. Golub, Diffuse large B-cell lymphoma outcome prediction by geneexpression profiling and supervised machine learning. Nat Med 8 (2002) 68-74.

[44] S.S. Dave, K. Fu, G.W. Wright, L.T. Lam, P. Kluin, E.J. Boerma, T.C. Greiner, D.D. Weisenburger, A. Rosenwald, G. Ott, H.K. Muller-Hermelink, R.D. Gascoyne, J. Delabie, L.M. Rimsza, R.M. Braziel, T.M. Grogan, E. Campo, E.S. Jaffe, B.J. Dave, W. Sanger, M. Bast, J.M. Vose, J.O. Armitage, J.M. Connors, E.B. Smeland, S. Kvaloy, H. Holte, R.I. Fisher, T.P. Miller, E. Montserrat, W.H. Wilson, M. Bahl, H. Zhao, L. Yang, J. Powell, R. Simon, W.C. Chan, and L.M. Staudt, Molecular diagnosis of Burkitt's lymphoma. N Engl J Med 354 (2006) 2431-42.

[45] D.R. Carrasco, G. Tonon, Y. Huang, Y. Zhang, R. Sinha, B. Feng, J.P. Stewart, F. Zhan, D. Khatry, M. Protopopova, A. Protopopov, K. Sukhdeo, I. Hanamura, O. Stephens, B. Barlogie, K.C. Anderson, L. Chin, J.D. Shaughnessy, Jr., C. Brennan, and R.A. Depinho, High-resolution genomic profiles define distinct clinico-pathogenetic subgroups of multiple myeloma patients. Cancer Cell 9 (2006) 313-25.

[46] D.J. Wong, H. Liu, T.W. Ridky, D. Cassarino, E. Segal, and H.Y. Chang, Module map of stem cell genes guides creation of epithelial cancer stem cells. Cell Stem Cell 2 (2008) 333-44. 


\begin{tabular}{|c|c|c|c|c|}
\hline Tissue & Oct4 & Sox2 & KLF4 & c-MYC \\
\hline Lymphoma & no & no & no & yes \\
\hline Leukemia & yes & no & yes & yes \\
\hline Myeloma & no & no & yes & yes \\
\hline Adrenal & no & no & no & no \\
\hline Bladder & yes & yes & no & no \\
\hline Blood & no & no & no & no \\
\hline Brain & yes & yes & yes & yes \\
\hline Breast & no & no & no & yes \\
\hline Cervix & no & no & no & no \\
\hline Chondrosarcoma & no & no & no & no \\
\hline Colon & no & yes & no & yes \\
\hline Endocrine & no & no & no & no \\
\hline Endometrium & no & no & no & no \\
\hline Esophagus & no & no & no & no \\
\hline Gastric & no & no & no & no \\
\hline Head-Neck & no & no & no & yes \\
\hline Liver & no & yes & no & no \\
\hline Lung & yes & yes & no & yes \\
\hline Melanoma & no & no & no & no \\
\hline Mesothelioma & no & no & no & no \\
\hline Multi-cancer & no & yes & no & no \\
\hline Muscle & no & no & no & no \\
\hline Neuroblastoma & no & no & no & no \\
\hline Oral & no & no & no & no \\
\hline Others & no & no & no & no \\
\hline Ovarian & yes & no & no & no \\
\hline Pancreas & yes & no & no & yes \\
\hline Parathyroid & no & no & no & no \\
\hline Prostate & yes & yes & yes & yes \\
\hline Rectum & no & no & no & no \\
\hline Renal & yes & no & no & yes \\
\hline Salivary-gland & no & no & no & yes \\
\hline Sarcoma & no & no & no & no \\
\hline Seminoma & yes & yes & no & yes \\
\hline Skin & no & no & no & no \\
\hline Testis & yes & yes & yes & no \\
\hline Thyroid & no & no & no & no \\
\hline Uterus & no & no & no & no \\
\hline
\end{tabular}

\section{Table 1}

Ovrer-expression of SOX2, OCT4, KLF4 and c-MYC in human tumor types to that of their normal tissue counterparts using publicly available gene expression data, including the Oncomine Cancer Microarray database. 


\begin{tabular}{|l|c|c|c|c|}
\hline cancer type & sox2 & Oct4 & KIf4 & c-Myc \\
\hline Bladder & + & & & \\
\hline Brain & + & + & + & \\
\hline Breast & + & + & & + \\
\hline Cervix & + & & & \\
\hline Colon & + & & & \\
\hline Endometrium & + & & & \\
\hline Head-Neck & + & + & & + \\
\hline Lung & & & & + \\
\hline Lymphoma & & & & + \\
\hline Melanoma & & & + & + \\
\hline Ovarian & & & + & \\
\hline Pancreas & & & & + \\
\hline Prostate & & & & + \\
\hline Renal & + & & & \\
\hline Sarcoma & + & + & & \\
\hline Thyroid & + & & & \\
\hline
\end{tabular}

\section{Table 2}

Association sox2, oct4, Klf4 and c-Myc with tumor grade 


\begin{tabular}{|l|l|l|l|c|}
\hline $\begin{array}{l}\text { cancer } \\
\text { type }\end{array}$ & sox2 & Oct4 & KIf4 & c-Myc \\
\hline Bladder & & & & \\
\hline Brain & & & & + \\
\hline Breast & & & & + \\
\hline Colon & & & & \\
\hline Head-Neck & & & & \\
\hline Leukemia & & & & + \\
\hline Liver & & & & + \\
\hline Lung & & & & + \\
\hline Lymphoma & & & & \\
\hline Melanoma & + & & & \\
\hline Myeloma & + & & & \\
\hline Ovarian & + & & & \\
\hline Prostate & & & & \\
\hline Renal & & & & \\
\hline
\end{tabular}

Table 3

Association of sox2, Oct4, Klf4 and c-Myc with prognosis in cancer. 
Figure $1 \mathrm{~A}$ : Association of c-Myc expression with prognosis

Multiple Myeloma - Relapse Status - 1 Year

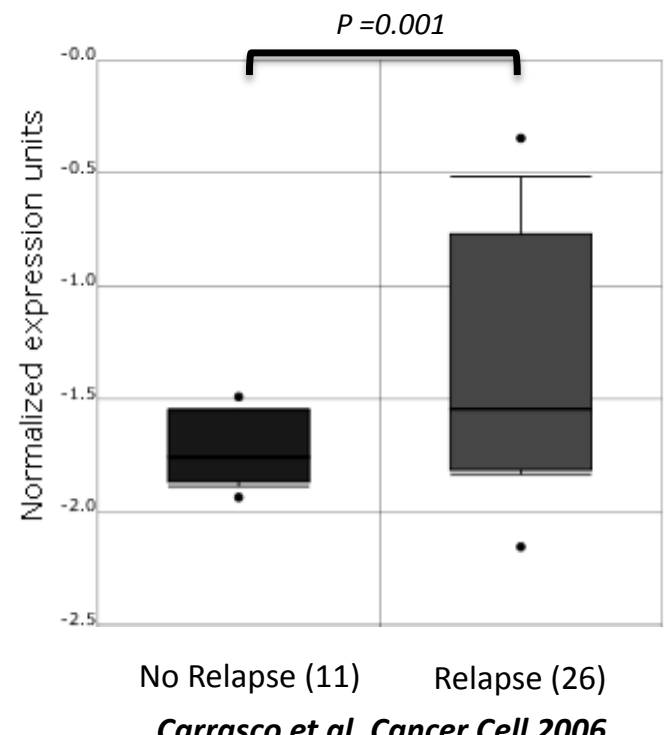

Carrasco et al. Cancer Cell 2006

Diffuse Large B-Cell Lymphoma - Survival - 5 Years

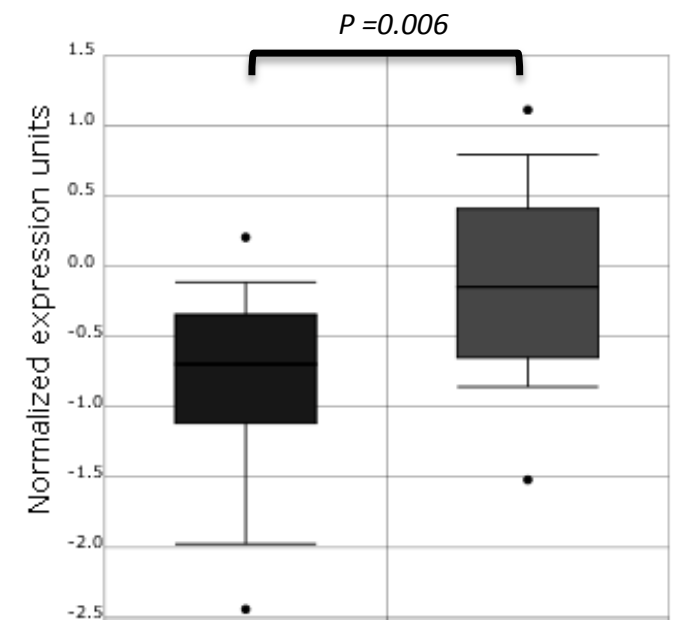

Alive (15) Dead (26)

Shipp et al. Nat Med 2002

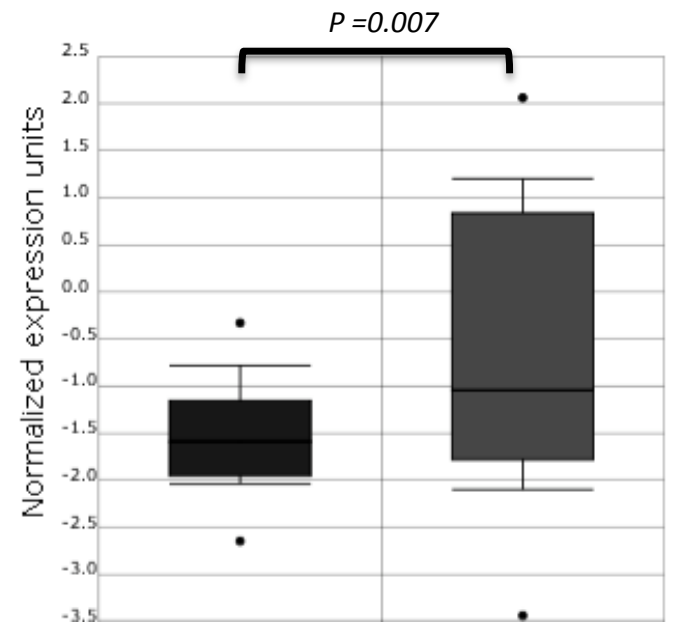

Alive (23)

Dead (31)

Alizadeh et al. Nature 2000
Breast Carcinoma - Overall Survival - 5 Years

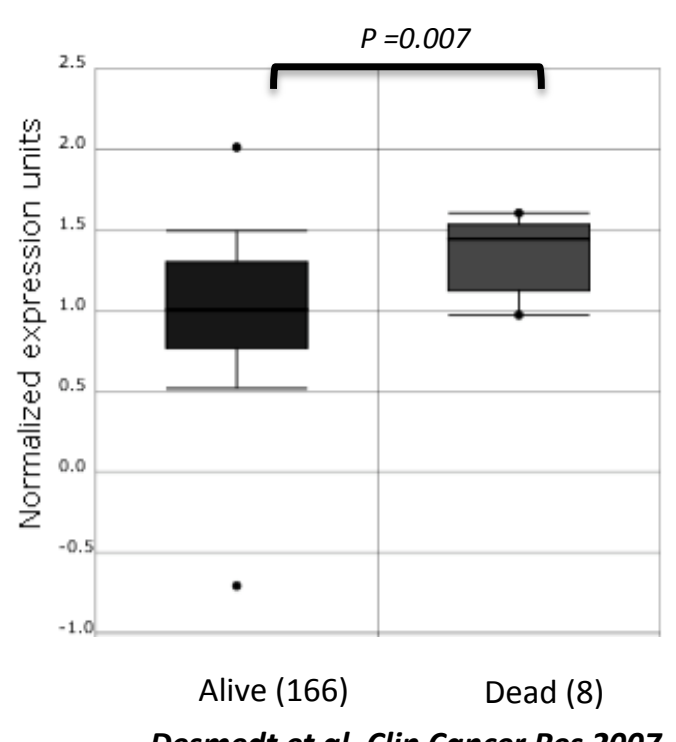

Desmedt et al. Clin Cancer Res 2007

Burkitt's Lymphoma - Survival - 5 Years

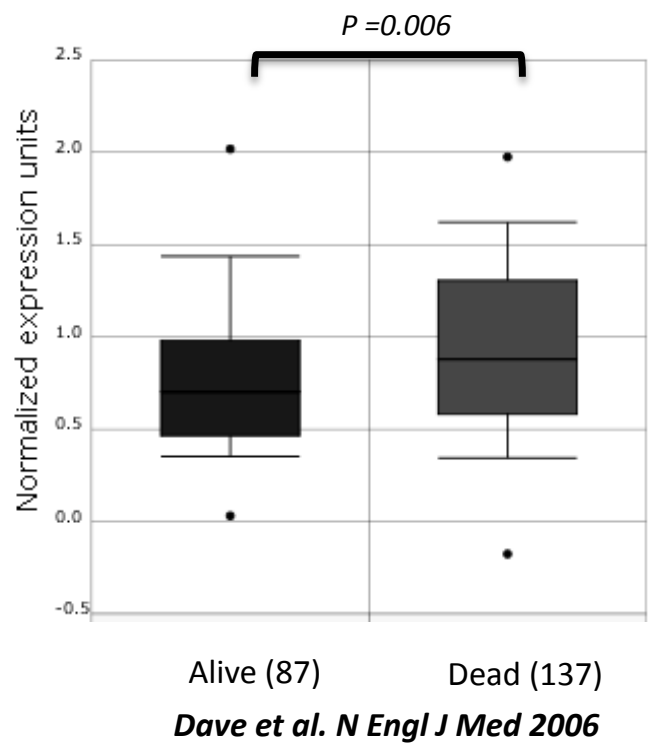


Non-Small Cell Lung Cancer - Survival - 5 Years

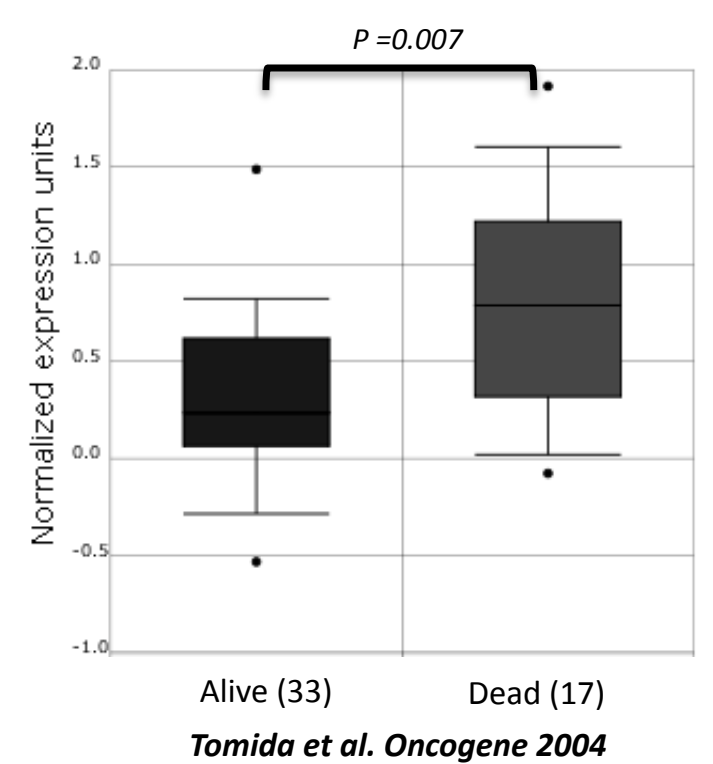

Brain - Survival - 3 Years

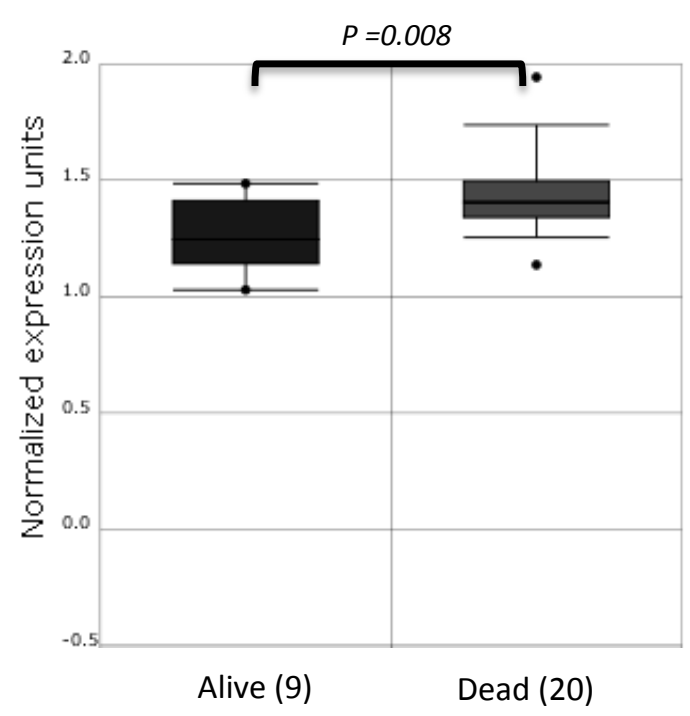

Shai et al. Oncogene 2003 
Figure $1 \mathrm{~B}$ : Association of Sox 2 expression with prognosis

Ovarian Carcinoma - Survival - 5 Years
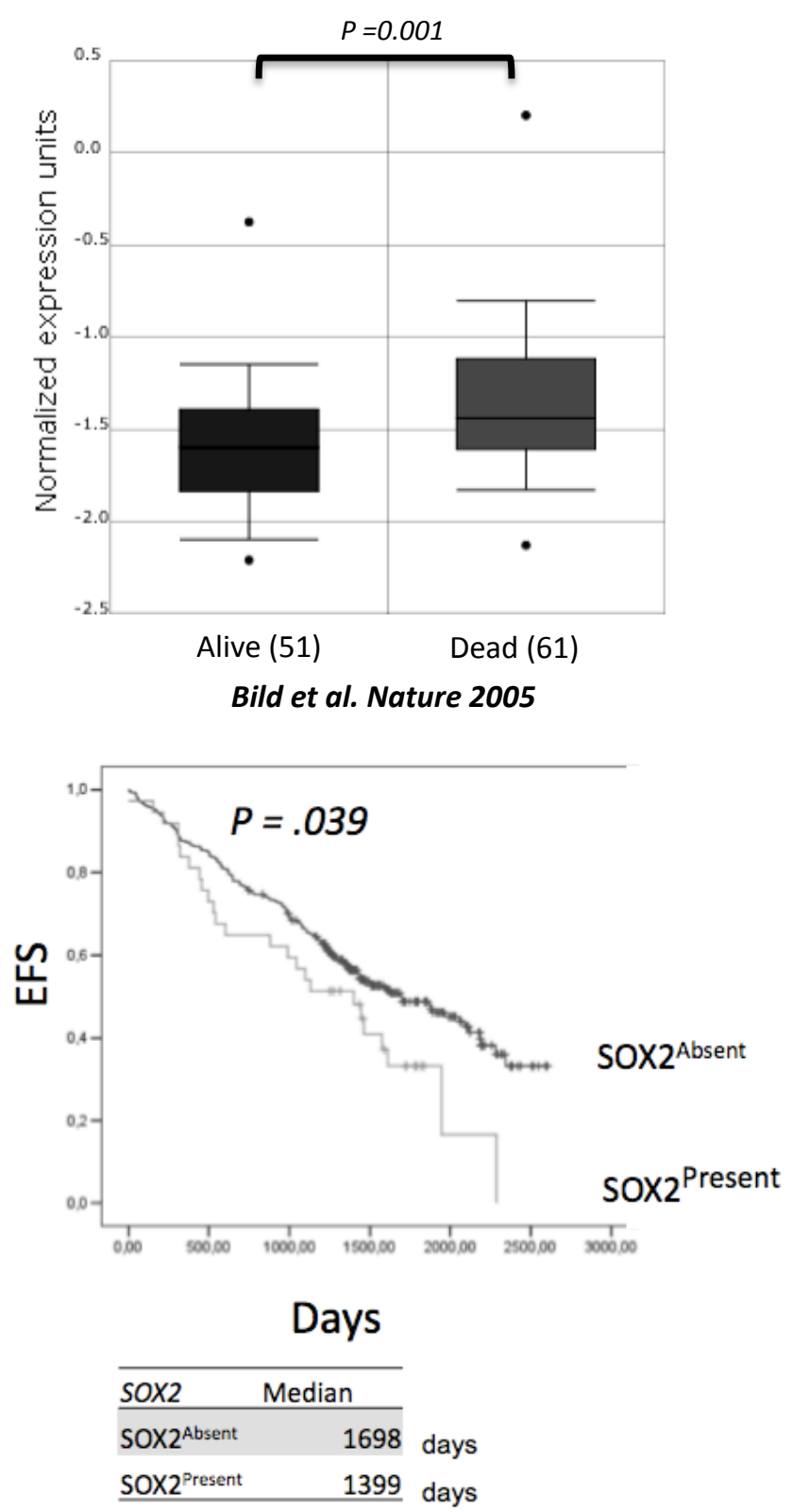

Melanoma Metastasis Tumor - Survival - 3 Years
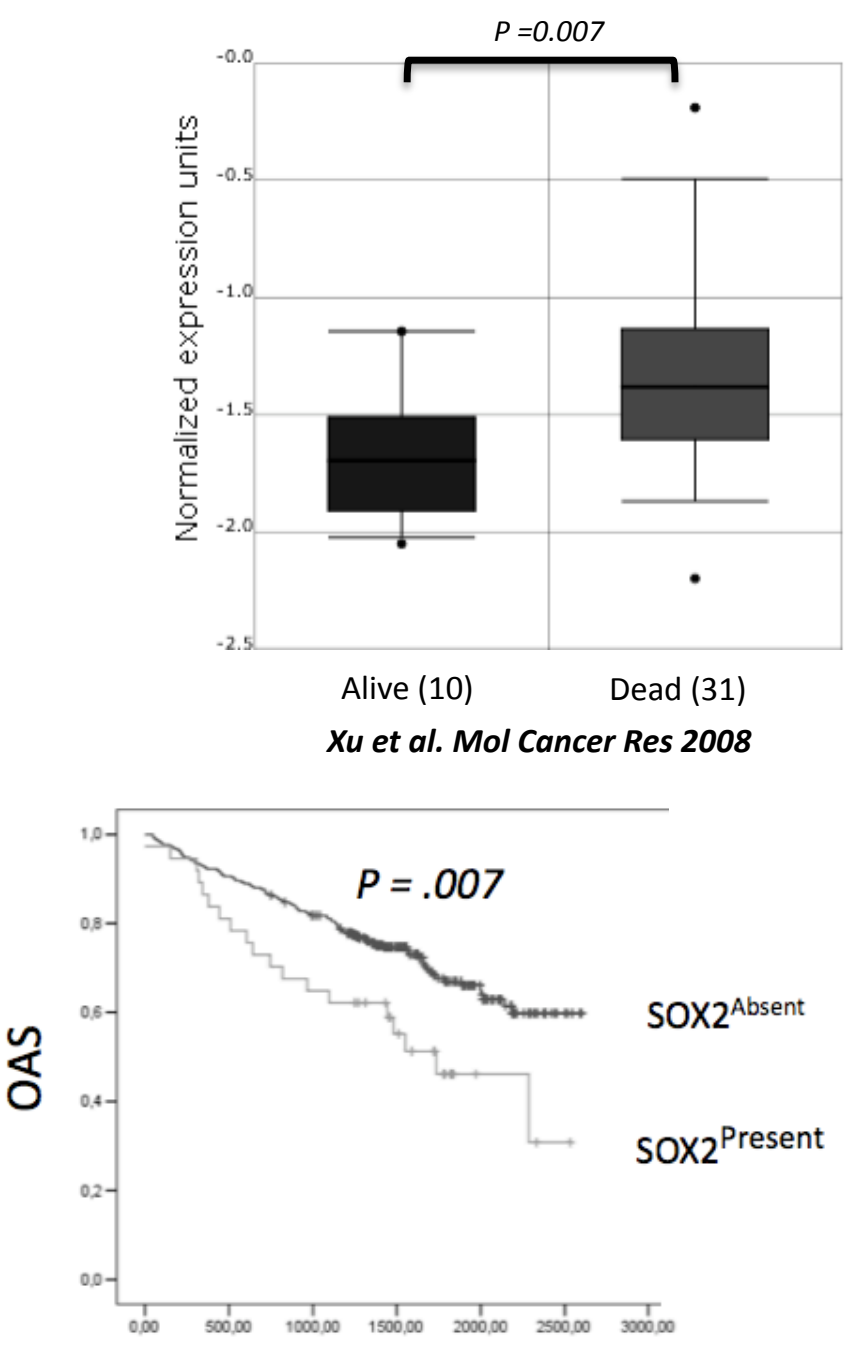

Days

\begin{tabular}{lr}
\hline SOX2 & Median \\
\hline SOX2 & \\
SObsent & 1466 \\
SOX2 & days \\
\hline
\end{tabular}

